\title{
ACCOUNTANCY IN THE MIDST OF A SURPLUS- VALUE-ADDING INTER-FUNCTIONAL DEVELOPMENT PROCESS
}

\author{
Heli Hookana \\ Turku School of Economics \\ heli.hookana@tse.fi
}

June 2007

\begin{abstract}
This article builds on the notion that, in order to meet the increasing management requirement for data, successful in-house accountancy professionals are internalising ever more capabilities and responsibilities, thereby reflecting a partnership role in professions related to basic operations. The study investigates the organisational interfaces of the accountancy profession vis-à-vis other professions during the change process. The findings identify some possible factors contributing to the traditional way of producing and utilising accounting information, and suggest some possible measures to be used as key facilitators in starting a change process aimed at securing an enlarged, more customer-oriented and highly interactive role for accountancy. The contribution of the study lies in increasing our understanding of surplusvalue-producing inter-professional development processes. In addition, based on the case of rescue services the study provides a holistic view on accountancy knowledge management in public-sector services provided in inter-municipal cooperation.
\end{abstract}

Keywords:

Cross-functional interfaces, accountancy profession, public financial management, knowledge management, rescue services, inter-municipal cooperation 


\section{INTRODUCTION}

This study provides an insight into the current international process of change in the management of the public sector, ranging from decentralisation and privatisation to the development of goal-driven and client-oriented organisations (Osbourne \& Gäbler, 1992; Helden, 2005). In connection with these changes, management techniques from the private sector, denoted as New Public Management (see Hood, 1995), were introduced in many publicsector organisations. These techniques were mainly related to financial management, and were labelled New Public Financial Management by Olson, Guthrie and Humprey (1998).

The study also contributes to the growing body of literature on the enlarged organisational role of the accountancy profession as a part of information and knowledge management (e.g., Hopper, 1980; Granlund \& Lukka, 1998; Bhimani \& Keshtvarz, 1999; Velayutham \& Rahman, 2000; Burns \& Baldvinsdottir, 2005). The challenge involved in the role shift to meet the data requirements - advocated in the literature and welcomed in practice - faced by the accountancy profession essentially means a cultural transition from number crunching towards business partnership. It imposes increased ability requirements on accountancy personnel and further demands on the functional professions and top management facing increasing efficiency and effectiveness targets.

Thus, the different professions (e.g., Abbott, 1988) are increasingly assuming a partnershiporiented attitude, which is also connected with more active inter-professional interfaces. The ongoing public-sector transformation away from its traditional producer-driven ethos towards behaviour that is more responsive to citizens as customers of services and that promotes effectiveness and efficiency, leads us to assume that the same kind of process is going on in the public sector as well. Overall, the requirements for cooperation between different professions reflect the strong need to transform an organisation's financial management into more of a surplus-value-producing operation, in other words into a function producing information that is more useful for management purposes. This, in turn, enables quick, timely and relevant management decisions in organisations that have been drawn into the public-sector transformation process. In this way, the accountancy profession aims to enhance the abilities of the functional professions and top management to equip them to bear their increasing accountability responsibilities.

The paper is structured as follows. The second section specifies the research questions. The research methods are outlined in the section that follows. The section thereafter gives the empirical analysis. The final two sections offer a discussion of the case and provide some conclusions.

\section{RESEARCH PUESTIONS}

The aim of this paper is to contribute to the research on the enlarged organisational role of the accountancy function with reference to efforts to reduce accounting-information preparer-user perception gaps, and to provide an insight into the current process of change in the financial management of the public sector. The analysis draws upon an in-depth empirical investigation into the attempts of one inter-municipal organisation, the Emergency Services of Satakunta, to develop its accounting information and to advance management accountability. 
In particular, by means of interdisciplinary analysis the study:

- investigates the organisational interfaces of the accountancy profession vis-à-vis other professions during the inter-functional change process;

- explains the background for the traditional, non-value-adding way of producing and utilising accounting information;

- identifies some possible measures to be used as key facilitators in starting a change process aimed at securing a more surplus-value-adding role for accountancy.

Most previous studies on the ability of accountancy professionals to meet the information needs of business-related managers have been based on surveys of accountants themselves (see Clarke, Thornley \& Stevens, 1999; Innes, Mitchell \& Sinclair, 2000). Among the first to focus on the use of accounting information by managers was the study conducted by Simon, Guetzkow, Kozmetsky and Tyndall (1954), and user perceptions have become increasingly prominent in accounting research since the 1990s (e.g., Shields, 1995; McGowan, 1998; Pierce \& O’Dea, 2003).

In particular, there is only scant empirical evidence of the relational interplay between the professions concerning accounting changes. Studies by Scapens and Roberts (1993), Granlund (2001), Roslender and Hart (2003) and Siti-Nabiha and Scapens (2005) are examples of ones in which both viewpoints are taken into consideration, but exploration of the essence of the interplay between the professions and the measures introduced for intensifying that interface remains quite superficial. Moreover, little attention has been given to coordination among organisational functions (e.g., Munro \& Hatherly, 1993; Mouritsen, 1996).

Scant as previous research on inter-functional interfaces within private-sector management is, there are even fewer investigations of accounting-information preparer-user perception gaps within the public sector. The process of assuming a customer-and market-oriented attitude and a form of behaviour that promotes effectiveness and efficiency in service provision is only in its infancy in the public sector, and furthermore, the significance of accounting information and the role of the accountancy profession has only recently been acknowledged (see e.g., Olson et al., 1998).

\section{RESEARCH METHOD}

The starting point of this study was a consultation request from a Finnish local-government body. The researcher was asked to help to clarify the drawing up and use of accountancy information in this inter-municipal organisation aiming to achieve effectiveness and efficiency, and to propose suggestions for its development. The author was invited into the case organisation of the Emergency Services of Satakunta in November 2004, and the last interviews mapping the development are planned for summer 2007.

The research aim was to combine participation in development work in practice with making a theoretical contribution, the latter by attempting to solve real-world problems (see e.g., Czarniawska, 2001; Lukka, 2005; Inanga \& Scheiner, 2005). The researcher makes a purposeful intervention in the target company and, as a result, in part creates its reality (see e.g., Evered \& Louis, 1981; Yin, 1984). Intervention is seen as a route to the development processes of the target case. Further, the interventional mode incorporates a pragmatic test of the usefulness of knowledge produced from a scientific viewpoint (see e.g., Mattessich, 1995; Lukka 2005). 
The applied mode of action research can be characterised as deconstructive, which allows that incommensurability is inevitable in organisations involving a plurality of localised understandings and practices (Cassell \& Johnson, 2006). Due to the nature of the theory linkage of the study, the aim of which is to elaborate further on prior theory concerning the organisational role of accountancy and on accounting-information preparer-user perception gaps, theoretical clarification, elaboration and refinement are achieved through the analysis of the essence of the inter-professional relationships within the misfit-resolution process, as well as by broadening the scope of the study to include the public sector (see e.g., Lukka, 2005; see also, Keating, 1995).

Overall, the study is methodologically action-oriented and subjectivist. The analysis aims at furthering understanding of and explaining by interdisciplinary analysis the accounting practices emerging in the examined inter-municipal organisation (see e.g., Ryan, Scapens \& Theobald, 1992; Scapens, 1990 and 2004). This approach is supported by arguments presented in the area of critical accounting (see e.g., Roslender, 1996; Inanga \& Schneider, 2005), which refers to accountants' and data users' own projects of seeking a greater level of self-awareness in an attempt to understand the conditions and consequences of the practice of financial data management. The focus of the research is on accounting-related change processes within organisations and between professions, although the importance of external institutions is also acknowledged (see e.g., Burns \& Scapens, 2000; Siti-Nabiha \& Scapens, 2005).

The findings are analysed first on the basis of individual interviews conducted with the different local-government participants, financial-data producers and users, and secondly on the basis of different workshops in which the problems of accountancy and accountability were discussed interactively between the researcher and the persons at hand. The personal interviews, in which the idea was to elicit the interviewee's explanation of the existing problems and his or her suggestions for better practices, were open and semi-structured to enable similar issues to be addressed with different personnel. The interviewees produced a total of approximately 30 hours' worth of material. The interviews were tape-recorded and transcribed.

On the other hand, the workshops provided occasions on which to address the interfaces between the professions and to externalise and disseminate the financial knowledge related to the company (see e.g., Nonaka \& Takeuchi, 1995). The workshops took between two and four hours. Twelve workshops were arranged altogether, each attended by 10-30 providers and users of financial data in the case organisation.

The researcher used direct observation as a research method during the periods of time she spent in the case organisation. She visited the organisation and met the personnel on several different occasions during the consultancy undertaking. She was also invited as an expert to the meetings of the supreme authority (the advisory committee, see below) held during the consultancy undertaking, and to some meetings of the management group. The managers of the units provided some of the written material describing the organisational image, and the accounting personnel supplied some of the main financial reports of the target organisation.

By firmly situating her investigation of the case company in its context, and by connecting it to previous empirical and theoretical research, the author aimed at producing findings that extend beyond the case organisation in terms of theoretical scope (see e.g., Lukka \& Kasanen, 1995), the problems of which are universal. Of course, the rhetoric is to be judged by the readers of the study. 


\section{A CASE ENGAGED IN A DEVELOPMENT PROCESS - THE EMERGENCY SERVICES OF SATAKUNTA}

\subsection{Organisational image}

Despite the recommendations of the government and the Finnish Ministry of the Interior, voluntary cooperation between the municipalities within the fire and emergency services did not materialise, and consequently the regional organisations were brought under the rule of law. The aim was to increase the efficiency and influence of the services through the joint regional use of scarce municipal resources.

The regional emergency services were due to have come into existence by 1 January 2004. One of these regional organisations is the case organisation, the Emergency Services of Satakunta, which covers all the 26 municipalities in the region with its ca. 230,000 inhabitants. The annual budget of the Emergency Services totals approximately $€ 16.5 \mathrm{~m}$. The operations of the Emergency Services are primarily financed by the municipalities. The government gives funding for investments (ca. $20-30 \%$ of the required sum). The Services operate in 51 locations with around 250 full-time personnel. There are also 1,200 volunteers in the 50 emergency units of the volunteer fire brigade.

The cooperation started on the understanding that the total costs would not change, and that the municipalities would be able to exploit their existing resources more efficiently in providing higher-quality services. The operation of the Emergency Services of Satakunta is based on a cooperation agreement between the municipalities, which defines the inter-municipal organisational model, the division of costs and the governance structure.

\subsection{The inter-municipal organisational model and governance structure}

According to the cooperation agreement, the responsible municipality, the town of Pori, appoints an advisory committee to administer the work of the Emergency Services of Satakunta. The 26 member municipalities elect their representatives on the committee, which has, among other things and after hearing the views of the municipalities, the right to decide on the service level of the emergency services. Furthermore, it prepares an annual plan of action and a budget, approves the allocation scheme, and decides on the establishment and loss of positions, on the general principles of the use of funds, and on how the costs are divided between the municipalities. It is also responsible for approving the board of directors' report.

The Director of the Emergency Services acts as the presiding official on the advisory committee. The director is in charge of developing the operations, finances and organisation of the Emergency Services. There are four administrative operational sectors, which are managed by $a$ District Chief Fire Officer, assisted by officials in the day-to-day work of the emergency services. Each operational sector has a work group acting as a cooperative body between the municipalities that are party to the cooperation.

\subsection{The personnel of the regional organisation}

A precondition of the new organisation was that the officials in the municipalities would be able to continue working in their offices in the same municipality in which they had been working 
before. No changes were made in the fire-brigade network. When the Emergency Services started their operations, all the personnel were transferred to the responsible municipality as former office holders.

The regional emergency services were inaugurated without the financial-management resources being increased. It was estimated that the existing personnel in the municipalities would be able to cope with financial and administrative matters during the transition period. Because of the lack of cohesion, however, a new financial manager was recruited for a fixed term, starting 1 October 2004, to develop the joint financial-management practices. The term was extended in spring 2005.

In addition to the financial manager, the current accounting personnel of the case organisation consisted of one person looking after the bookkeeping of the joint emergency services and one office employee taking care of the bookkeeping in each administrative operational sector. Previously, the chief fire officers in all 26 municipalities, together with the clerical staff, were responsible for financial matters. The office employees of the joint organisation were recruited from among the previous municipal clerical staff. The bookkeeping formed the basis for compiling annual budgets and financial statements, which were mainly included in the responsibilities of the financial manager.

\subsection{Development needs in the financial management, spring 2005}

Following the preparatory interviews with the Director of the Emergency Services, the financial manager, the four District Chief Fire Officers and the municipal management during December 2004 and June 2005, the researcher compiled a SWOT analysis of the Emergency Services in terms of financial management (see TABLE 1 ). This stage of the research process, in which the interfunctional interfaces were identified, was a crucial one because it paved the way for the reciprocal learning process (see e.g., Partanen, 2001). The SWOT analysis was further developed through creative dialogue in four workshops, one in each administrative operational sector, during which the regional work groups, the municipal management and the officers of the Emergency Services agreed that it highlighted the critical problems in the case organisation.

The descriptions of the interviews (see below) further illuminate the circumstances of the target organisation at the beginning of the research process. Overall, the personnel and the municipal owners of the Satakunta Emergency Services were quite like-minded concerning the development process. Some of them put forward sounder arguments than others, but their complaints as well as their suggestions for improvement were confirmed afterwards in the group discussions or in other confidential settings. The role and expertise of the accounting and finance personnel in producing the financial information required by the management were not questioned (see e.g., Cooper, 1996a, 1996b; Siegel \& Sorensen, 1999). It was more a matter of making more use of the financial information produced currently in order to advance the expanding accountability.

\subsubsection{Elected local-government representatives and municipal managers}

Despite the deficiencies in the legibility, relevance, future orientation and timeliness of the accountancy, the decisions on steering the joint organisation were made on the basis of the summarising follow-up accounting reports. Examples of the contradictory statements reflecting the confused states of minds among the municipal owners occur in the following citations, for instance. 
When the preliminary decision to launch the organisation was made, the cost details were pondered upon very thoroughly ... Before the financial manager was recruited, we did not know anything about the financial situation of the joint organisation. Now the financial reporting is of high quality and we know the state of affairs in good time ... (a municipal manager) ... There are no fundamental development needs in the financial reporting ... Small developments have taken place on all fronts ... the financial reports should be on time ... the municipalities lie about their expenditure ... (an elected local-government representative)

The inconsistent statements on the quality of the accounting system were accompanied by references to inadequate management resulting in a lack of clarity in accountability relationships.

... indicates the top management's inability to make decisions and implement them in practice ... inability to make preparations for the meetings ... (an elected local-government representative) ... the District Chief Fire Officers should be given the authority to take care of their sectors ...an elected local-government representative) ... the development programme has been neglected ... the pressure to develop the financial management has perhaps not been sufficient ... (an elected local-government representative)

The elected local-government representatives and the municipal managers characterised the role of the political representatives as making comprehensive and far-reaching decisions ... officials are experts in the fire and emergency services ... they see the whole from a narrower perspective ... (an elected local-government representative)

\section{TABLE 1: SWOT analysis of the Satakunta Emergency Services from the perspective of financial} management

STRENGTHS (objectives) OPPORTUNITIES

The joint regional use of the scarce resources of the municipalities (personnel, equipment) $\Rightarrow$ efficiency and influence.

The resources of the chief fire officers of the small municipalities are freed to concentrate on core tasks $\Rightarrow$ influence and quality management.

The administration, financial matters and acquisitions that can be managed at a distance are taken care of on the regional level $\Rightarrow$ efficiency.

The personnel resources are increased in the area of financial management.

The financial management is more transparent and comparable on the branch level.

Results are achieved through cooperation between the paid full-time personnel and the voluntary fire brigade.

The development of the financial management of the utility to support strategic decision-making.

The effective use of the working time of the paid full-time personnel.

Guaranteeing adequate resources for the joint acquisition of equipment through a common acquisition policy.

Structural changes in the utility, such as decreasing the number of emergency duty areas.

Common values, vision and strategy are truly connected with the rescue duties on all organisational levels to support the accountability of the officers.

Proactive prediction of the changes in the operational environment $\Rightarrow$ effective continuous development based on initiative.

Quality management (service ability and 
customer satisfaction).

\section{WEAKNESSES}

The differences between the bookkeeping systems and the financial-management cultures of the municipalities with their different resources, and the lack of common financialmanagement principles make the system fragmented and the reporting non-comparable.

The insufficient use of financial reporting in the directing of the activities on different decision-making levels (deficiencies in reporting and/or in exploiting it)

Lack of clarity connected with the internal management system concerning accountability.

The exchange of financial information is not sufficient among the funding municipalities, the officers and the highest management level; discussion is not interactive.

The public image of the utility as "a glutton for costs".

The district chief fire officer and the regional work groups are not informed of the working of the committee $\Rightarrow$ information breaks hinder accountability.

Due to breaks in information flow district work groups do not act as "links" between the sectors and the committee as agreed in the cooperation agreement.

Not overrunning the budget is a goal in itself.

\section{THREATS}

The municipalities and the personnel of the emergency services stick to focusing on municipal interests.

The municipalities prioritise costs according to the level of service.

Deficits in the municipal budgets continue.

Resistance to change among the officers: accountability is not assumed.

The highest-level management does not give space to or create opportunities for officer accountability.

Source: Interviews and workshops held during December 2004 and June 2005

\subsubsection{The Director of the Emergency Services}

The Director of the Emergency Services was generally satisfied with the financial information he received. It arrived on time and was, without a doubt, drawn up by experts. However, the problem is particularly the fact that the financial data produced does not create any development measures in the service production. The data somehow remains half-used. ...the users of the information should realise the developmental needs themselves. 
He also stressed his willingness to develop governance principles. He blamed the District Chief Fire Officers for not taking action on this matter. All kinds of development measures have been initiated in recent months, but they never really got properly started. ... in the management group I have long-lasting, vague and non-committal discussions with the District Chief Fire Officers, but ... I have to do all the preparations myself ...

The separate nature of the financial management was quickly apparent. ...as long as the management group remains a chatting forum, the financial manager need not attend the meetings...l do not support the practice in which the service professional also takes care of management matters... The district level is a suitable target when you're making efforts to develop the financial management within our organisation.

\subsubsection{Officers responsible for the rescue services}

According to the officers the finance-related governance principles had been developed on the district level, which resulted in the current scattered nature of the management function and the lack of accountability relationships. The need for a common financial language and system was expressed, as well as for the determination of common organisational principles. We have to clarify the process ... the target for service provision is to be set ... the follow-up information system ought to be constructed ... (a District Chief Fire Officer). They all agreed that various developmental plans had been started in the company, but many of them had, for one reason or another, remained mainly on the "level of talk".

The roles of the Director, the management group and the district work groups were described as minor in terms of accountability. Complaints of information breaks in the flow of financial data were frequently expressed. Without clear responsibilities and information on accountability the handling of financial matters is, at best, based on the employee's morality ... the officials are not committed ... (a District Chief Fire Officer).

The areas in need of development appeared to concern arrangements related to forecasts for projects and human resources. We have plenty of financial data ... what is essential for steering services ... a few fire officers).

There was a strong wish for more detailed financial figures covering the targeted results. On the other hand, the public-sector officials found these figures rather odd. I would like to have more information comparing the concrete results of the districts and the fire brigades ... some of them feel that I say wicked things about the others (a District Chief Fire Officer).

Despite highlighting the importance of the financial figures, a great deal of attention was given to the citizens for whom the services were provided. In this context, it was a question of fulfilling the moral duty to provide reliable security services to the customers. Fault has never been found with the fire and emergency services we have supplied ... it is only the finance-related issues that we're blamed for... (a District Chief Fire Officer).

\subsubsection{The financial manager and the accounting personnel}

On the whole, the accounting personnel had certain strengths worth mentioning. They had a wealth of expertise, built up through long work experience in one municipality. However, there was wide variation in the organisation of the fire and emergency services in the municipalities. At the point of constructing the joint services we were not given any instructions for taking care 
of financial matters ... each of the districts and fire brigades compiled their own reports and carried out bookkeeping in their own way... (an office employee in one of the administrative sectors)

The financial manager admitted that information did not flow from the officers responsible for the rescue services to the accountancy staff when they needed something from the administrative operational sectors or the municipalities. However, if I am asked to help more in the decision-making related to the service provision, I will need more time and resources (the financial manager).

\subsection{Developmental measures, autumn 2005 - autumn 2006}

The separate and "autonomous" production and utilisation of financial data seemed to be the fundamental problem, the consequences of which were reflected in various aspects of the data management and in the problems that emerged during the assignment. The separate financial function was revealed in the mode of organisation and interaction (for instance, the minor role of the management group and the district meetings of the officers in following the finances, and the delegation of almost all responsibilities for follow-up to the financial manager by the Director of the Emergency Services), as well as in expressed sentiments to the effect that none of stakeholders had ever found fault with the fire and emergency services; only finance-related issues had been criticised. Although they were stressed, matters of efficiency, effectiveness and accountability were considered to be something different from the provision of essential fire and emergency services by the officers responsible for the rescue services: in this they also included the top management of the Emergency Services.

The cross-functional cooperation and, partly connected to that, the decentralisation of accountancy-related devices, have also been mentioned in many previous studies on accounting as measures concentrated on enhancing the business orientation of the accountancy profession (see e.g., Chenhall \& Langfield-Smith, 1998; Granlund \& Lukka, 1998; Järvenpää, 2002). In addition, the author turned to the literature on the structure and governance of organisations, as well as on internal customer orientation (see e.g., Jaworski \& Kohli, 1993; Grönroos, 1998; Conduit \& Mavondo, 2001). The relocation of facilities, e.g., spatial proximity referring to the inverse physical distance between functional groups (Allen 1986), personnel movement as in multifunctional training (Griffin \& Hauser, 1996), organisational structure and re-designing efforts (Barcley, 1991), incentives and rewards (Hauser, Simester \& Wernerfelt, 1994), and formal integrative management processes such as building up cross-functional teams (Griffin \& Hauser, 1996), have been referred to as commonly used integrative devices (see also e.g., DeRuyter \& Wetzels 2000 for a summary analysis of the organisational methods of enhancing the interfaces between professions).

The integrative devices of relocation and spatial proximity (Allen, 1986), organisational redesigning efforts aiming at joint rather than individual efforts (Barcley, 1991), and crossfunctional teams (Griffin \& Hauser, 1996) could be combined with the thinking behind experiential learning in close inter-professional interaction (Kolb, 1984; Nonaka \& Takeuchi; 1995). The necessary learning and developmental incentives are available only in interaction, which produces independent experiential learning.

Given the integrative devices deliberated on in the literature on organisations and accounting, the method adopted in this study, i.e. which of critical research and the implications gleaned from the interviews, the researcher concluded the process by presenting three groups of 
developmental measures, all of which were interconnected:

- a "shaking up of ideas";

- providing regular forums for experiential, custom-oriented learning; and

- teaming up the accountancy personnel with the other professions.

TABLE 2: The empirical interventions of the study

\begin{tabular}{|c|c|c|}
\hline "Shaking up of ideas" & Regular forums for learning & Inter-professional teaming up \\
\hline $\begin{array}{l}\text { To encourage new innovative } \\
\text { attitudes and to think } \\
\text { critically about why they acted } \\
\text { in the way they did. }\end{array}$ & $\begin{array}{l}\text { Monthly meetings in each } \\
\text { administrative operational } \\
\text { sector under the chairmanship } \\
\text { of the District Chief Fire } \\
\text { Officer. }\end{array}$ & $\begin{array}{l}\text { Set up on different } \\
\text { organisational levels as the } \\
\text { effective way of team building }\end{array}$ \\
\hline $\begin{array}{l}\text { During the interviews, } \\
\text { workshops and different } \\
\text { administrative meetings. }\end{array}$ & $\begin{array}{l}\text { Twice a year, during the periods } \\
\text { of budgeting and the closing of } \\
\text { the accounts, the financial } \\
\text { officer attends the district } \\
\text { meetings. }\end{array}$ & $\begin{array}{l}\text { Occasions for experiential, } \\
\text { inter-professional, custom- } \\
\text { oriented learning and for } \\
\text { achieving more productive } \\
\text { governance }\end{array}$ \\
\hline $\begin{array}{l}\text { To enable the accountancy } \\
\text { staff to offer new regional- } \\
\text { level financial information and } \\
\text { to prove their ability to provide } \\
\text { an array of services meeting } \\
\text { the users' information needs. }\end{array}$ & $\begin{array}{l}\text { A few times a year, the } \\
\text { municipal top management } \\
\text { meet to discuss matters } \\
\text { related to the joint Emergency } \\
\text { Services from the perspective } \\
\text { of the whole province also } \\
\text { attended by the top } \\
\text { management of the Emergency } \\
\text { Services. }\end{array}$ & $\begin{array}{l}\text { Each member of the team had } \\
\text { his or her own distinct role in } \\
\text { steering the inter-municipal } \\
\text { organisation }\end{array}$ \\
\hline $\begin{array}{l}\text { To enable the officers } \\
\text { responsible for the rescue } \\
\text { services to assume a new } \\
\text { regional-level mode of } \\
\text { behaviour and to prove their } \\
\text { ability to apply the accounting } \\
\text { data while aiming at effective } \\
\text { and efficient service provision. }\end{array}$ & $\begin{array}{l}\text { The District Chief Fire Officers } \\
\text { attend the advisory committee } \\
\text { meetings. }\end{array}$ & $\begin{array}{l}\text { Clarified and tightened the } \\
\text { network of local-government } \\
\text { elected representatives, } \\
\text { municipal managers and } \\
\text { officers responsible for the } \\
\text { rescue services. }\end{array}$ \\
\hline
\end{tabular}

Source: Interdisciplinary analysis on the basis of the interviews and the workshops held during autumn 2005 and autumn 2006

These interventions in the target organisation are summarised in TABLE 2. Most obviously, the very cross-functional encounters alerted the different professions to the need to take into account the viewpoints of the other functions in striving for their common goals (e.g., Narver \& Slater, 1990; Jaworski \& Kohli, 1993; Conduit \& Mavondo, 2001). The objective was to get the professions to realise the significance of their own roles within information and knowledge management in value-adding terms. A further positive outcome was that the workshops served as a general in-house multifunctional training event in accordance with the company's strategic guidelines (see e.g., Griffin \& Hauser, 1996; c.f. also Maltz \& Kohli, 2000). 


\subsection{Change in views on accountancy within the tightening network}

The aim of this study was to increase our understanding of the developing role of the accountancy function on the path to more effective governance and to clearer management accountability within the public sector. The importance of a common language (see e.g., Nonaka \& Takeuchi, 1995; Jönsson, 1996) and networking skills were particularly highlighted. The nature and essence of the accounting service is elaborated further in cross-functional teams so as to tailor it to users' needs. Moreover, teams offering multiple viewpoints on the company's knowledge management provide forums for disseminating feedback on the quality of the service.

The emphasis of the research was on the accounting-related change processes that were influenced by the internal institutions, i.e. the accounting-related culture (see e.g., Burns \& Scapens, 2000; Siti-Nabiha \& Scapens, 2005). Minor developments in accounting methods and techniques were evident. The study thus highlights the problems involved in seeking to classify particular episodes of accounting change as either successful or unsuccessful (see e.g., SitiNabiha \& Scapens, 2005). Progress was made, at least from the perspectives of the organisational members (see also e.g., Chua, 1995; Partanen, 2001 on different types of accounting change).

The culture of financial-data management in the Emergency Services could be said to have changed incrementally: members of the organisation have sought to accommodate differing interpretations and practices, while still retaining the core identity of an accountancy professional (see e.g., Reger, Mullane \& Gustafson \& DeMarie, 1994; Caccia \& Steccolini, 2006). In the light of the case evidence, accounting change could be managed as an ongoing process rather than as a sequence of rational events (Dawson, 1994; Burns, 2000). Thus, the learning style in the case organisation could be characterised as action-oriented (see e.g., Partanen, 2001): organisational values motivate the data producers and users to develop interpersonal, intervention and communication skills in order to cooperate in and cross over interfaces, whereas the attitude to new management-accounting techniques is reserved (see e.g., Partanen, 2001). The accounting innovation pursued can be characterised as transformational, referring to the evolution of a new structure (i.e., an inter-municipal network of clearer and more productive accountability relationships), which also results in a change in the organisational strategy and vision (see e.g., Clarke \& Lapsley, 2004); it was not only the financial management, but also the structure and vision of the case organisation that were under development, especially from the standpoints of the municipal owners and the top management.

The case organisation is probably a typical case of the neglecting of activities such as accountancy that support the essential business, and the placing of too great an emphasis on the growing essential business or service provision. It may well be, as Hedberg and Jönsson (1978) and Granlund (2001) argue, that the accounting function provides an organisational baseline against which to measure change. There is less inclination to adjust this baseline, in this case traditional municipality-focused accounting systems even if they are known to provide somewhat false information, in the midst of other organisational changes: indeed, some continuity may be necessary to enable change in essential service functions (Burns \& Scapens, 2000).

The traditional accounting jargon was strongly questioned in the case organisation, the aim being to produce accounting information that supported increased effectiveness and efficiency 
and broadened management accountability to include citizens and municipalities (see, e.g., Roberts \& Scapens, 1985; Roberts, 1991 and 2001; Collier, 2005). Somewhat paradoxically, these undefined social accountabilities in particular are now given considerable attention, which further increases the accounting-information producer-user gap. The tax-paying public is considered an important party to which the officials are accountable, but not in terms of the effectiveness and efficiency commonly expected in the provision of public services. There was a discrepancy between what the accounting measures were intended to achieve and what they produced (see also e.g., Mulgan, 2000; Robinson, 2003). In addition, there were certain hidden areas of accountability (see, e.g., Collier, 2006) due to the advisory committee's lack of opportunity to engage in informed discussion.

For instance, the hidden area of accountability was revealed in the use of the budgeting system, which was found to be the most important organisational process with respect to accountability in the public sector (see also e.g., Goddard, 2004). There was a clear, partly self-reinforcing but not value-adding, illusion of a rigorous accounting system that gave information to the municipal owners in a rational and neutral manner, and a presumption that the calculations would identify the absolute truth (Pettersen, 2004; Collier, 2006). To a large extent, the accounting system strengthened the legitimacy of the traditional narrow way of thinking that existed in the separate municipalities, rather than promoting the viewpoint of the whole province. It was also used to smooth over the political conflicts of interest between the municipal owners. The budget system was used to balance budgets, but it gave limited information to managers as input in decisions to enhance the effective use of resources (see also Lapsley, 1994; Pettersen, 2004).

In a loose network of municipalities, accounting functions to seal the relationships (see e.g., Lind \& Thrane, 2005). Apart from its minor use in managing and measuring the effectiveness of the inter-municipal organisation, the accounting system forced the network partners to interact with each other, thereby creating joint service production (see. e.g., Jönsson \& Solli, 1993; Mellemvik, Gårseth, Nesbakk \& Olson, 2005). The contribution of the accounting language is mostly positive, and necessary for creating representations of accountability space. On the other hand, as referred to in Chabrak (2005) and Pesqueux (2005), for example, lacking or deficient accounting systems may result in the failure to recognise the socially constitutive, holistic and casuistic understanding of the reality in public-sector organisations in particular.

As Roslender (1996) and Willmott, Cooper and Puxty (1993), among others, have stated, studying the conditions of contemporary accounting labour necessitates extending the boundaries of what is normally presented as the work of accountants, i.e. public practice, to include the totality of accounting roles and employment, and to capture the interest of a much broader range of practitioners. This study has sought to show how conditions are enacted through discursive practices that are articulations of specific complexes of inter-professional relations (see e.g., Ezzamel et al., 2004).

Roslender (1996) refers to the opportunities to use unqualified staff to carry out the significant amounts of work entailed in the provision of accounting services. A secondary accounting labour force potentially exists, which could fill many of the lowest-level accounting posts (see also e.g., Cooper 1996a, 1996b and Siegel \& Sorensen, 1999; Samuel, Dirsmith \& McElroy, 2005). On the evidence of this study, so-called secondary accounting professionals really exist, but they present no threat: on the contrary, the other professionals can and must make their contributions to the surplus-value production of financial-knowledge management by assuming a co-operative attitude (see also e.g., Roslender \& Hart, 2003 on the call for the integration of 
marketing-management insights into the area of strategic accounting). Strategic accounting producing market-oriented, forward-looking and long-term information could be argued to be an interdisciplinary concept (see also Hookana-Turunen, 1998 on reflections of interdisciplinarity in the strategic management of corporate foreign exchange). In the case organisation, the previous knowledge of financial matters held by the municipal fire chiefs contributed to their secondary accounting role.

For almost as long as the case organisation has existed there have been complaints about its governance principles and calls to improve them. The clarification and enlargement of the role of the accountancy produced a more systematic and better organised model of joint behaviour within the rescue services. The sets of nodes and ties representing the relationships between the different parties were defined more accurately, which paved the way for the adoption of more successful governance and accountability principles within this network structure. During the first years of the existence of the case organisation the network has resulted in a greater similarity of accountability perceptions (see, e.g., Brass, Galaskiewicz, Greve \& Tsai, 2004, for the antecedents of networks) and homogeneity and "averageness" in practices and costs (see e.g., Llewellyn \& Northcott, 2005), but the process is still going on. Clearly, it will take another couple of years before these fundamental cultural movements become established practice and result in higher effectiveness and efficiency in the joint service production (see e.g., Pollitt, Birchall \& Putman, 1999 on problems related to the measuring of better performance in the public sector).

\section{CONCLUSION}

The research results show the importance of the organisational interfaces of the accountancy profession vis-à-vis other professions during the process of change into a value-adding part of the organisation. Surplus-value-adding organisational finance-related knowledge management calls for merging the different kinds of inter-professional accountabilities into a coherent totality rather than a focus on function. In addition, the findings identified some possible factors contributing to the traditional way of producing and utilising accounting information (the separate and "autonomous" production and utilisation of financial data and the related factors), and suggested some possible measures to be used as key facilitators in starting a change process aimed at securing an enlarged and more customer-oriented role for accountancy in supporting the increase in management accountability (innovative and critical thinking, forums for learning, inter-professional teaming up). At best, the organisational formality in terms of structure, principles and procedures supports informal communication, and vice versa.

Overall, the case findings supported the previous literature on accounting change, particularly with reference to aspects of cultural change (see e.g., Caccia \& Steccolini, 1996; Burns, 2000; Granlund, 2001; Partanen, 2001; Clarke \& Lapsley, 2004). Moreover, previous research on publicsector financial management has shed some light on problems such as the isolation of accountancy professionals (see e.g., Olsen et al., 1998; Caccia \& Steccolini, 2006) and the need for skills in relationship management (e.g., Zolkievski, 2004), as well as on the difficulties involved in measuring cooperative frameworks for the provision of public services (e.g., Kurunmäki \& Miller, 2006). The major theoretical contribution of this longitudinal case study is that, unlike previous studies (see also Olsen et al., 1998 and Mellemvik et al., 2005), it provides deeper perceptions on circumstances for exploiting the surplus-value-producing wholeness of 
accountancy-related information and inter-functional partnerships within organisational knowledge management.

In comparison with previous research on the organisational role of the accountancy profession, this study highlights the apparent differences in accounting-change processes between organisations operating in the public and private sectors (see e.g., Ittner \& Larcker, 1998; Barton, 2004; Catasus \& Grönlund, 2005). Overall, the municipal culture is still quite far removed from the business-oriented culture, and the processes are more functional than process-based (Clarke \& Lapsley, 2004). On the other hand, there seem to be many similarities related to the cultural basis of financial management (connected, for instance, to inter-professional cooperation and changing professional roles). Furthermore, the trend of demanding ever more successful governance principles in organisations (see e.g., Hermalin, 2005) is also evident in the public sphere.

Theory contribution was pursued in an attempt to solve real-world problems (see e.g., Inanga \& Scheiner, 2005; Helden, 2005), which involved the pragmatic testing of the usefulness of knowledge produced from the scientific viewpoint (see e.g., Mattessich, 1995; Lukka 2005). Further, the innovation-implementation process was not top-down. If changes are to have a real impact on key practitioners, then there should be a clear interest in and access to information this point was stressed in this interventionist case study (see e.g., Jacobs, Marcon \& Witt, 2004).

The development of accounting methods and techniques that serve the joint cooperation and measure its impact on and consequences for society is ongoing. Furthermore, this study will continue by focusing on the network dynamics across different levels in the case organisation, for instance. The anticipated result of these further investigations is to add profundity and new dimensions to the concepts of value-adding accountability and governance in the public sector.

\section{Acknowledgment}

The author wishes to acknowledge the comments offered at the Adding Value in the Financial World - A 2020 Perspective Conference, 16-18 0ctober 2006 in South Africa, and thank the anonymous referees for their comments and suggestions on the earlier drafts of the paper.

\section{REFERENCES}

Abbott, A. (1988). The System of Professions, an Essay on the Division of Expert Labour. London: The University of Chicago Press, Ltd.

Allen, T. J. (1986). Managing the Flow of Technology. Cambridge: MIT Press.

Barclay, D.W. (1991). Interdepartmental Conflict in Organizational Buying: The Impact of Organizational Context. Journal of Marketing Research, 28(2), pp. 145-160.

Barton, A.D. (2004). How to Profit from Defence: A Study in the Misapplication of Business Accounting to the Public Sector in Australia. Financial Accountability \& Management, 2(3), pp. 281-304.

Bhimani, A. \& Keshtvarz, M. H. (1999). British Management Accountants, Strategically Oriented. Journal of Cost Management, 13(2), pp. 25-31.

Brass, D. J., Galaskiewicz, J., Greve, H. R. \& Tsai, W. (2004). Taking Stock of Networks and Organizations: a Multilevel Perspective. Academy of Management Journal, 47(6), pp. 795-817.

Burns, J. (2000). The Dynamics of Accounting Change, Inter-Play between New Practices, Routines, 


\section{H Hookana}

Institutions, Power and Politics. Accounting, Auditing and Accountability Journal, 13(5), pp. 566-596.

Burns, J. \& Scapens, R. W. (2000). Conceptualising Management Accounting Change: an Institutional Framework. Management Accounting Research, 11(1), pp. 3-25.

Burns, J. \& Baldvinsdottir, G. (2005). An Institutional Perspective of Accountants' New Roles - The Interplay of Contradictions and Praxis. European Accounting Review, 14(4), pp. 725-257.

Caccia, L. \& Steccolini, I. (2006). Accounting Change in Italian Local Governments: What's Beyond Managerial Fashion? Critical Perspectives on Accounting, 17(2-3), pp. 154-174.

Cassell, C. \& Johnson, P. (2006). Action Research: Explaining the Diversity. Human Relations, 59(6), pp. 783-814.

Catasus, B. \& Grönlund, A. (2005). More Peace for Less Money: Measurement and Accountability in the Swedish Armed Forces. Financial Accountability \& Management, 21(4), pp. 467-484.

Chabrak, N. (2005). The Politics of Transcendence: Hermeneutic Phenomenology and Accounting Policy. Critical Perspectives on Accounting, 16(6), pp. 701-716.

Chenhall, R. \& Langfield-Smith, K. (1998). Factors Influencing the Role of Management Accounting in the Development of Performance Measures within Organizational Change Programs. Management Accounting Research, 9(2), pp. 361-386.

Chua, W. F. (1995). Experts, Networks and Inscriptions in the Fabrication of Accounting Images: a Story of the Representation of Three Public Hospitals. Accounting, Organizations and Society, 2(3), pp. 111-145.

Clarke, P, Thornley Hill, N. \& Stevens, K. (1999). Activity-Based Costing in Ireland: Barriers to and Opportunities for Change. Critical Perspective on Accounting, 10(4), pp. 443-468.

Clarke, P. \& Lapsley, I. (2004). Management Accounting in the New Public Sector, Editorial. Management Accounting Research, 15(3), pp. 243-245.

Collier, P. M. (2006). Costing Policy Services: The Politization of Accounting. Critical Perspectives on Accounting, 17(1), pp. 57-86.

Conduit, J. \& Mavondo, F. T. (2001). How Critical Is Internal Customer Orientation to Market Orientation? Journal of Business Research, 51(1), pp. 11-24.

Cooper R. (1996a). Look out, Management Accountants (Part 1.) Management Accounting, May, pp. 20-26.

Cooper R. (1996b). Look out, Management Accountants (Part 2.) Management Accounting, June, pp. 35-40.

Czarniawska, B. (2001). Having Hope in Paralogy. Human Relations, 54(1), pp. 13-21.

Dawson, P. (1994). Organizational Change: a Processual Approach. London: Paul Chapman Publishing.

Evered, R. \& Louis, M. R. (1981). Alternative Perspectives in the Organizational Sciences: "Inquiry from the Inside" and "Inquiry from the Outside". Academy of Management Review, 8(3), pp. 385-295.

Goddard, A. (2004). Budgetary Practices and Accountability Habitus. Accounting, Auditing and Accountability Journal, 17(4), pp. 543-577.

McGowan, A. S. (1998). Perceived Benefits of ABCM Implementation. Accounting Horizons, 12(1), pp. 
$31-50$.

Granlund, M. \& Lukka, K. (1998). Towards Increasing Business Orientation: Finnish Management Accountants in a Changing Cultural Context. Journal of Management Accounting Research, 9(2), pp. 185-211.

Granlund, M. (2001). Towards Explaining Stability in and around Management Accounting Systems. Management Accounting Research, 12(2), pp. 141-166.

Griffin, A. \& Hauser, R. (1996). Integrating R\&D and Marketing: a Review and Analysis of the Literature. Journal of Product Innovation Management, 13(3), pp. 191-216.

Grönroos, C. (1998). Service Marketing Theory, Back to Basics. Swedish School of Economics and Business Administration (Working Papers). Helsinki: SHS Intressebyrå AB (Oy Casa Security Ab).

Hauser, J. R., Simester, D. \& Wernerfelt, B. (1994). Customer Satisfaction Incentives. Marketing Science, Fall, pp. 327-350.

Hedberg, B. \& Jönsson, S. (1978). Desinging Semi-Confusing Information Systems for Organizations in Changing Environments. Accounting, Organizations and Society, 3(1), pp. 47-64.

Helden, J. van G. (2005). Researching Public Sector Transformation: The Role of Management Accounting. Financial Accountability and Management, 21(1), pp. 99-133.

Hermalin, B. દ. (2005). Trends in Corporate Governance. The Journal of Finance, 60(5), pp. 2351-2384.

Hood, C. (1995). "The New Public Management" in the 1980s: Variations on a Theme. Accounting, Organizations and Society, 20(2-3), pp. 93-109.

Hookana-Turunen, H. (1998). Decision-making and Strategy in Corporate Foreign Exchange Management. Decision-makers in Their Organisational and Social Contexts. Paper presented at the Second Asian Pacific Interdisciplinary Research in Accounting Conference, Osaka City University, Japan, 4-6 June 1998.

Hopper, T. (1980). Role Conflicts of Management Accountants and Their Positions within Organisation Structures. Accounting, Organizations and Society, 5(4), pp. 401-411.

Inanga, દ. L. \& Schneider, W. B. (2005). The Failure of Accounting Research to Improve Accounting Practice: a Problem of Theory and Lack of Communication. Critical Perspective on Accounting, 16(3), pp. 227-248.

Innes, J., Mitchell, F. \& Sinclair, D. (2000). Activity-Based Costing in the UK's largest Companies: a Comparison of 1994 and 1999 Survey Results. Management Accounting Research, 11(3), pp. 349362.

Jacobs, K., Marcon, G. \& Witt, D. (2004). Cost and Performance Information for Doctors: an International Comparison. Management Accounting Research, 15(3), pp. 337-354.

Jaworski, B. \& Kohli, A. (1993). Market Orientation: Antecedents and Consequences. Journal of Marketing, July, pp. 53-70.

Jönsson, S. (1996). Accounting for /mprovement. Oxford: Pergamon.

Jönsson, S. \& Solli, R. (1993). "Accounting Talk" in a Caring Setting. Management Accounting Research, 4(4), pp. 301-320.

Järvenpää, M. (2002). Johdon laskentatoimen liiketoimintaan suuntautuminen laskentakulttuurisena muutoksena - vertaileva case-tutkimus (Business Orientation of Management Accounting as a Cultural Change - a Comparative Case Study). Publications of The Turku School of Economics 
and Business Administration A: 5:2003.

Kolb, D. A. (1984). Experiential Learning. Experience as a Source of Learning and Development. New Jersey: Prentice Hall.

Keating, P. J. (1995). A Framework for Classifying and Evaluating the Theoretical Contributions of Case Research in Management Accounting. Journal of Management Accounting Research, Fall, pp. 66-86.

Kurunmäki, L. \& Miller, P. (2006). Modernising Government: The Calculation Self, Hybridisation and Performance Measurement. Financial Accountability and Management, 22(1), pp. 87-106.

Lapsley, I. (1994). Responsibility Accounting Revived? Market Reforms and Budgetary Control in Health Care. Management Accounting Research, 5(3-4), pp. 337-352.

Lind, J. \& Thrane, S. (2005). Network Accounting. In: Jönsson, S. \& Mouritsen, J. (eds). Accounting in Scandinavia, the Northern Lights, pp. 115-137. Denmark: Liber \& Copenhagen Business School Press.

Llewellyn, S. \& Northcott, D. (2005). The Average Hospital. Accounting, Organizations and Society, 30(6), pp. 555-583.

Lukka, K. \& Kasanen, $\varepsilon$. (1995). The Problem of Generalisability: Anecdotes and Evidence in Accounting Research. Accounting, Auditing and Accountability Journal, 8(5), pp. 71-90.

Lukka, K. (2005). Approaches to Case Research in Management Accounting: the Nature of Empirical Intervention and Theory Linkage. In: Jönsson, S. \& Mouritsen, J. (eds). Accounting in Scandinavia, the Northern Lights, pp. 375-399. Denmark: Liber \& Copenhagen Business School Press.

Maltz, E. \& Kohli, A. K. (2000). Reducing Marketing's Conflict with Other Functions: the Differential Effects of Integrating Mechanisms. Journal of the Academy of Marketing Science, 28(4), pp. 479-492.

Mattessich, R. (1995). Conditional-Normative Accounting Methodology: Incorporating Value Judgements and Means-End Relations of an Applied Science. Accounting, Organizations and Society, 20(4), pp. 259-284.

Mellemvik, F., Gårseth-Nesbakk, L. \& Olson, 0. (2005). Northern Lights on Public Sector Accounting Research-Dominate Traits in 1980-2003. In: Jönsson, S. \& Mouritsen, J. (eds). Accounting in Scandinavia, the Northern Lights, pp. 299-319. Denmark: Liber \& Copenhagen Business School Press.

Mouritsen, J. (1996). Five Aspects of Accounting Departments' work. Management Accounting Research, 7(3), pp. 283-303.

Mulgan, R. (2000). "Accountability”: an Ever-Expanding Concept? Public Administration, 78(3), pp. 555-573.

Munro, R. \& Hatherley, D. (1993). Accountability and the New Commercial Agenda. Critical Perspectives on Accounting, 4(4), pp. 369-395.

Nonaka, I. \& Takeuchi, H. (1995). The Knowledge Creating Company. New York: Oxford University Press.

Olson, 0. J., Guthrie, J. \& Humprey, C. (eds) (1998). Global Warning: Debating International 
Developments in New Public Financial Management. 0slo: Cappelen.

Osbourne, D. \& Gäbler, T. (1992). Reinventing Government; How the Entrepreneurial Spirit is Transforming the Public Sector. New York: Plume.

Partanen, V. (2001). Muuttuva johdon laskentatoimi ja organisatorinen oppiminen (The Changing Management Accounting and Organisational Learning). Publications of The Turku School of Economics and Business Administration A: 6:2001.

Pesqueux, Y. (2005). Corporate Governance and Accounting Systems: a Critical Perspective. Critical Perspectives on Accounting, 16(6), pp. 797-823.

Pettersen, I. J. (2004). From Bookkeeping to Strategic Tools? A Discussion of the Reforms in the Nordic Hospital Sector. Management Accounting Research, 15(3), pp. 319-335.

Pierce, B. \& O’Dea, T. (2003). Management Accounting Information and the Needs of Managers. Perceptions of Managers and Accountants Compared. The British Accounting Review, 35(3), pp. 257-290.

Pollitt, C., Birchall, J. \& Putman, K. (1999). Letting Managers Manage: Decentralisation and Opting Out. In: Stoker, G. (ed) The New Management of British Local Governance, pp. 40-61. Great Britain: Macmillan.

Roberts, H. (1993). Accountability and Responsibility. The Influence of Organisation Design on Management Accounting. Maastricht: Universitaire Press.

Roberts, J. (2001). Trust and Control in Anglo-American Systems of Corporate Governance: the Individualizing and Socializing Effects of Processes of Accountability. Human Relations, 54(12), pp. 1547-1572.

Roberts, J. \& Scapens, R. (1985). Accounting Systems and Systems of Accountability - Understanding Accounting Practices in Their Organizational Contexts. Accounting, Organizations and Society, 10(4), pp. 443-456.

Robinson, P. (2003). Government Accountability and Performance Measurement. Critical Perspectives on Accounting, 14(1-2), pp. 171-186.

Roslender R. (1996). Critical Accounting and the Labour of Accountants. Critical Perspectives on Accounting, 7(4), pp. 461-484.

Roslender, R. \& Hart, S. J. (2003). In Search of Strategic Management Accounting: Theoretical and Field Study Perspectives. Management Accounting Research, 14(3), pp. 255-279.

De Ruyter, K. \& Wetzels, M. (2000). The Marketing-Finance Interface: a Relational Exchange Perspective. Journal of Business Research, 50(2), pp. 209-215.

Ryan, B., Scapens, R. W. \& Theobald, M. (1992). Research Method and Methodology in Finance and Accounting. London: Academic Press.

Samuel, S., Dirsmith, M. W. \& McElroy, B. (2005). Monetized Medicine: from the Physical to the Fiscal. Accounting, Organizations and Society, 30(3), pp. 249-278.

Scapens, R. W. (1990). Researching Management Accounting: The Role of Case Studies. The British Accounting Review, 22(3), pp. 259-281.

Scapens, R. S. (2004). Doing Case Study Research. In: Humprey, C. \& Lee. B. (eds.) The Real Life Guide to Accounting Research. A Behind-the-scenes View of Using Qualitative Research Methods. 


\section{H Hookana}

Amsterdam: Elsevier.

Scapens, R. W. \& Roberts, J. (1993). Accounting and Control: a Case Study of Resistance to Accounting Change. Management Accounting Research, 4(1), pp. 1-32.

Shields, M. D. (1995). An Empirical Analysis of Firms' Implementation Experiences with Activity-Based Costing. Journal of Management Accounting Research, 7, pp. 148-166.

Siegel, G. \& Sorensen, J. \&. (1999). Counting More, Counting Less, Transformations in the Management Accounting Profession. The 1999 Practice Analysis of Management Accounting, IMA.

Simon, H. A., Guetzkow, H., Kozmetsky, G. \& Tyndall, G. (1954). Centralization v Decentralization in Organizing the Controller's Department. New York: Controllership Foundation Inc.

Siti-Nabiha, A. K. \& Scapens, R., W. (2005). Stability and Change: an Institutionalist Study of Management Accounting Change. Accounting, Auditing and Accountability Journal, 18(1), pp. $44-73$.

Velayutham, S. \& Rahman, A. (2000). Towards Market Differentiation in the Accounting Profession: the Case of Australia and New Zealand. Critical Perspectives on Accounting, 11(6), pp. 691-711.

Venkatraman, N \& Ramanujam, V. (1986). Measurement of Business Performance in Strategy Research: a Comparison of Approaches. Academy of Management Review, 11(4), pp. 801-814.

Willmott, H., Cooper, D. \& Puxty, T. (1993). Maintaining Self-Regulation: making 'interests' coincide in discourses on the governance of the ICAEW. Accounting, Auditing and Accountability Journal, 6(4), pp. 68-93.

Zolkiewski, J. (2004). Marketization and the Delivery of UK Health Services - Three Case Studies. Journal of Business Research, 57(9), pp. 1012-1020.

Yin, R. (1984). Case Study Research: Design and Methods. Newbury Park: Sage Publications. 